\title{
マクロ経済への影響を踏まえた公共事業関係費の水準と 調達方法の裁量的調整についての基礎的考察
}

\author{
京都大学大学院 藤井 聡* $^{1}$ \\ 京都大学大学院 中野 剛志 $*^{2}$
}

By Satoshi Fujii and Takeshi Nakano

\begin{abstract}
本稿では, 国 (政府)の公共事業の財源についての政治的判断を支援することを企図して, マクロ経済動 向に及ぼす影響を加味しつつ, 公共事業関係費の「水準」と「調達方法」を毎年じのように「調整」していくべ きかの基本的な考え方を整理することを試みた. そして, 市場における需要が供給を上回っているインフレ 状況にある時には, インフレ緩和のために緊縮財政を基本とすることが得策であり, 公共事業においては, 公債ではなく, 必要に応じた増税の可能性も視野に収めながら税収によって財源を調達することが得策で あることを指摘した. 一方で, 逆にデフレ状況にある時には, デフレを緩和するための積極財政を基本とする ことが必要であり, そのための財源については, 定常的な税収に加えて公債を自国通貨建ての内債として 発行することが得策であることを指摘した.
\end{abstract}

【キーワード】物価, 国債, 税収

\section{1. 問題}

\section{（1）土木計画と公共事業関係費}

土木計画の中心的な仕事は, その時々の様々な 政治的, 地理的, 経済的状況を加味しながら, 道路 整備やダム建設, 港湾整備といった「公共事業」の具 体的な在り方を考えるといらものである. そして, そうし た公共事業の多くは, 数百億円や数千億円, 場合に よっては, 数兆円から数十兆円の財源を必要とする ものである.したがって, そうした公共事業は通常, 「政府」が財源を調達し，それを出動することによって 進められる. そして言うまでもなく, 公共事業の具体 的なかたちは, その政府の財源, 寸なわち「公共事 業関係費」の多室に直接依存寸る. それ故, 公共事 業関係費の水準, ならびにその調達方法をどうする のか, といら問題は, 土木計画における中心的課題 の一つである.

\section{（2）マクロ経済動向と公共事業関係費}

一方, 政府の財源の問題は, 一国の経済に重大 な影響を及ぼす。なぜなら政府は, 家計や民間企業 とは異なり, 取り扱う金額が桁違いに大きく, インフレ
やデフレ, そして, 雇用水準と言ったマクロ経済の動 向に影響を及ぼさざるを得ないからである. そして, 政府の主要な財源が税金と公債である点を踏まえる なら, 公共事業関係費の問題は, その国の「税制」と 金融市場における「金利」に直接, 重大な影響を及 ぼすものでもある.

\section{（3）政治と公共事業関係費}

この様に, 公共事業関係費の多䓖は, 土木計画を 通して日本の国土や経済・社会の在り方に重大な影 響を及ぼすのみならず, インフレやデフレの傾向, 税 制, 雇用水準, 金利といった一国のマクロ経済の動 向にも大きな影響を及ぼす問題なのである.

それ故, 近代国家においては, こうした重大問題 は一国の政治において重大な問題として取り扱われ るのが一般的である. 例えば日本においては, 公共 事業の財源の水準の決定は, 日本国政府と国会の 重要な任務となっている. 各年次の公共事業関係費 を含めた国家予算の決定は国会の最重要課題の一 つであり, その予算案の策定は日本国政府の最重要 課題の一つとなっているのである. 


\section{（4）公共事業の財源に関する「総合的」な政治 的判断の必要性と, 本稿の目的}

この様に, 土木計画の具体的なかたちを決定づけ ている公共事業関係費の多室の問題は, 一国のマク 口経済に重大な影響を及ぼす，それ故，政治的にそ の水準を決定するにあたっては, 土木計画の具体的 な内容の (ストック効果・施設効果を見据えた) 検討に 加えて, それがマクロ経済に及ぼす(事業効果・フ ロー効果等含めた) 影響を十分に加味することが必 要である. それ故, 例えば公共事業関係費を増大す ることがマクロ経済状況に良質な影響を及ぼす時期 にはそれを増大させ, 逆の場合には縮小させるという ような臨機応変な対応を採用することが, 政治的な総 合的判断として求められるのである.

本稿はこうした議論を踏まえ, 国 (政府)の公共事業 の財源についての総合的な政治的判断を支援する ことを企図して, マクロ経済動向に及ぼす影響を加味 しつつ, 公共事業関係費の水準と調達方法を毎年ど のように調整していくべきかの基本的な考え方を整理 するものである.

なお、本稿では, 公共事業がマク口経済動向に及 ぼす影響を考えるにあたり, 公共事業関係費の「水 準の高低」が及ぼす影響と,「調達方法の相違」が及 ぼす影響とに分離して考えることとする.ついては, 以下の 2 . では前者を, 後者についてはそれに続く 3. で述べる. そしてそれらの議論を踏まえて, 公共

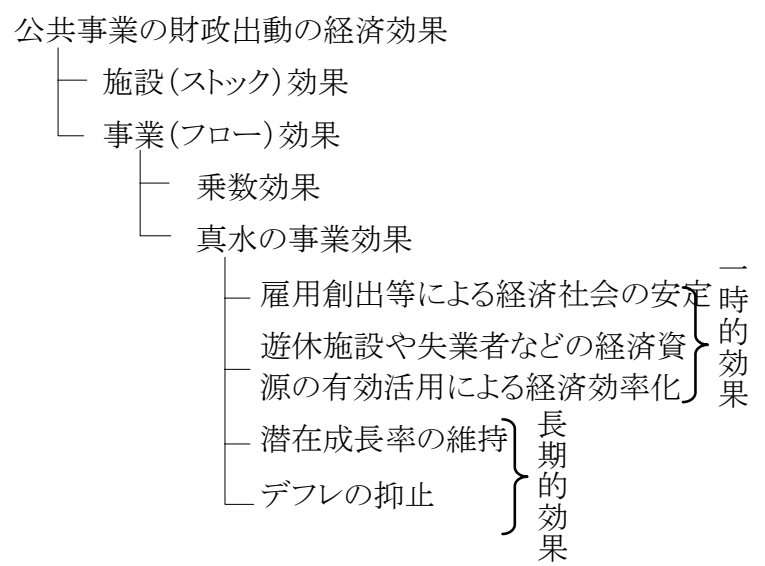

(中野(2010) $)^{13) 14)}$ を再整理)

図 1 公共事業の財政出動による経済効果の分類

事業関係費の水準と調達方法を毎年どのように調整 していくべきかの基本的な考え方を論ずる.

なお，上記の目的とする本稿では，日本銀行による 金融政策の議論については補足的に補注で述べる
に留める共に, そして, これまで土木分野で数多く論 じられてきた「どの様な施設を整備すべきか」といら議 論は他著(例えば1). 2) $)$ に譲ることとする.

\section{2.「公共事業関係費の水準」がマクロ経済動向に 及ぼす影響}

\section{（1）公共事業の経済効果}

「公共事業関係費の水準」がマクロ経済動向に及 ぼす影響については, 公共経済学においてこれまで 様々に論じられてきており, 多様な種類の影響が存 在することが指摘されている3), 4), 5), 6), 7), 8), 9), 10), 11), 12).こうした議論を踏まえ中野 $\left(2010^{13)} ; 2010^{14)}\right)$ はそ れらの議論の中で論じられてきた公共投資のマクロ 経済学的影響を図1の様に包括的に整理している.

まず, 公共事業の財政出動 (以下, 公共投資と呼 称する)の経済効果には, 施設効果と事業効果に分 類される. 施設効果とは, その「施設」の存在そのもの が及ぼす経済効果であり，事業効果とはその施設を つくる「事業」によってもたらされる効果である.

ここで, 施設効果とは例えば, 道路ができたことに よって当該地域の工場の生産性が向上する, といっ た効果であり,これまで土木計画学で論じられてきた 費用便益分析における「便益」で考慮されてきた各 種項目が，それに該当する.

一方で事業効果はさらに,「乗数効果」と「真水の事 業効果」の $2 つ に$ 分類されている. 乗数効果とは, 公 共投資によって有効需要が増加したときに、その直 接的な増加額よりもより大きく国民所得が増える現象 を言うものである. 例えば, 公共投資によって, 労働 者の賃金が増加する一方, その賃金を労働者が消 費に使うことで，また別の労働者の賃金が増加する， といった循環を通じて増加した国民所得の合計值が 乗数効果であり, ケインズを初めとして様々なマクロ 経済学の議論の中で論じられてきたものである.

一方,「真水の事業効果」とはこうした循環を通じて もたらされる乗数効果とは別の公共投資による直接 的な経済効果であり，以下の $4 つ の$ 効果が挙げられ ている(なお、この分類における「真水の事業効果」と は、一般に言われる「乗数効果」の中から、「直接的 な増加額よりもより大きく国民所得が増えた、その増 加分」を取り除いた部分を意味するものである). 
第一に, 公共投資によって雇用が創出され, 失業 者が救済されることを通じて,「経済社会が安定する」 といら効果がある.

第二に, 遊休設備 (使われずに放置されている生 産関連の施設)や失業者などの“経済資源”を有効 活用することよる経済全体の効率化, といら効果が挙 げられる。

以上の二点は, 以下に述べる $2 つ の$ 効果とは異なり, 短期的, 即効的に生ずる経済効果であり, しばしば “カンフル剤”としての効果として論じられてきたもの であり,これまでのマクロ経済に関する諸議論の中で も, 繰り返し指摘されてきたものである ${ }^{3)-6)}$.

さて, 以上の 2 つに加えた“長期的な真水の事業効 果”として, さらに以下の二つが指摘されている.

一つ目が「潜在成長率の維持」である.これは, 上 記の遊休施設や失業者等の経済資源の有効活用と も関連するが，そうした有効活用がもたらす “長期的 な効果”を意味するものである. すなわち, 設備廃棄、 失業による技能の喪失、研究開発投資削減を回避し、 これらの経済資源を維持することで潜在成長率の低 下を防ぐといら効果である.

そして二つ目の長期的効果が,「需要不足」を埋め 合わせ物価の下落を阻止することで、デフレを回避し、 民間の自律的な投資を促す，というものである。なお， デフレは, 物価と所得の低下循環的低下 (デフレス パイラル)を通じて, 場合によっては数十兆円, 数百 兆円といら巨大な経済損失をもたらすものであるから， これを回避するといら効果は, それと同じく数十兆円， 数百兆円という(機会費用的) 経済効果を意味するも のである.

\section{（2）デフレ期とインフレ期の相違}

さて, 以上に述べた公共投資のうち, 施設効果や 乗数効果はいずれも, マクロ経済状況がインフレー ション(インフレ)期であってもデフレーション(デフレ) 期であっても生じ得るものであるが，「真水の事業効 果」については, インフレ期であるのかデフレ期であ るのかによって, その存在が大いに異なったものと なってくる点に留意が必要である.

まず, インフレといらマクロ経済状況は, (財)市場に おける「供給」よりも「需要」の方が多い経済状況を言 う.つまり,「市場で提供されている財やサービスの金
額の総計」よりも,「各経済主体が欲しがっている財 やサービスの金額の総計」の方が多い経済状況で ある.これは「モノ不足」にある経済状況であり, その 結果, 財・サービスの值段が上昇していくこととなる。 こういら状況では, 生産者が財・サービスを生産すれ ば, それらは全て市場で売れることとなる.したがって, 生産者は生産を増加させるために労働者をたくさん 雇おうとするために失業率は低下し, 所持する施設 をフル活動させようとする. したがって「真水の事業効 果」を構成する 4 つの効果はいずれも存在せず「ゼ ロ」となる.

一方, デフレといらマクロ経済状況は, 市場におけ る「供給」よりも「需要」の方が少ない経済状況である. すなわち,「市場で提供されている財やサービスの金 額の総計」よりも,「各経済主体が欲しがっている財 やサービスの金額の総計」の方が少ない経済状況 である.これは「モノが有り余っている経済状況」であ り, その結果, 財・サービスの值段が低下していくこと となる.こういう状況では, 生産者が財・サービスをい くら生産しても, 市場で売れなくなってしまうため, 生 産者は, 経済活動を縮小しようとする. その結果, (い わゆるリストラによって) 失業者が生じ, 遊休施設が発 生することとなる. その結果, 潜在成長率も低下して いってしまうこととなる.こういう状況では, 公共投資に よって, 第四番目の「デフレの抑止」はもちろんのこと, 第一番目から第三番目の真水の事業効果がいずれ も, 生まれることとなる.

すなわち, 公共投資の経済効果の内, 「真水の事 業効果」については, インフレ期においては生じ得な い一方で, デフレ期においては生ずるものなのであ る.

\section{3.「公共事業関係費の調達方法」がマクロ経済 動向に及ぼす影響}

さて, 公共事業関係費の調達方法には, PFI や利 用者負担などの方法も考えられるが，公共事業関係 費全体に占める割合の大きさから言えば，一般的に は「税金」と「公債発行」が主要な方法である.

ここでは，「税金」で公共事業関係費を調達するの か,「公債発行」によって調達するのかの相違が, マ クロ経済に及ぼす影響について述べることとする. 


\section{（1）増税・減税の影響}

まず, 公共事業関係費を税金で調達する場合を述 心゙る事としよう. 税金には消費税, 所得税, 法人税, 固定資産税, そして揮発油税など, 様々なものがある が, 公債発行との比べた場合, それらの特徵は，(資 産の所有なども含めた) 国民の経済活動を中心とし た諸活動に関連するかたちで徵収される, というもの である. それ故, 少なくとも税収に基づく財政出動に よる諸効果を加味しなければ15)，「増税」はそれらの 諸活動を「縮減」させる効果を持つ一方，「減税」はそ れらを促進させる効果を持つ。

\section{（2）公債発行の影響}

一方, 公債によって財源調達をする場合, 公債の 発行額は, 税金とは異なって国民の諸活動の規模と は直接関係しない.ただし, 公債は金融市場で取引 されるものであるから, 公債発行額の増減は, 金融市 場の需給バランスに直接的な影響を及ぼす.

ここに金融市場とは, 各経済主体が経済活動を行う にあたっての財源調達のための市場である. 一般に, 金融市場における各経済主体の選択は「資金を調 達」するという「負債」をつくる行為と,「資金を貸し付 ける (＝預金する)」という「金融資産」を作る行為の二 種類のうちのいずれかというものである.ここでは簡 単のために前者の行為を「借金」, 後者の行為を「貸 し付け」と呼ぶこととしよう.この用語を使うなら, 政府 による公債発行といら行為は「借金」を行う行為という ことになる.

さて，金融市場は,こうした「貸し付け」は金融の「供 給」を意味し，「借金」は金融の「需要」を意味する. そして, 金融についての潜在的需要が金融供給を上 回った場合(つまり，借金をしようとする人が過剩にな り)「金利」(=借金をした際の利子)が上昇することと なる，逆に，金融についての需要がその供給を上 回った場合 (貸し付けをしようとする人が過剰になり) 「金利」が低下することとなる。

さて,こうした金融市場における需給バランスは, マ クロ経済状況がインフレにあるのかデフレにあるのか で異なったものとなる. まず, インフレ期においては, 物価が上昇するが, 物価上昇とは, 貨幣の価值が低 下していくこをを意味する. したがって, オカネを貸し てもそれが返ってくる頃にはその価值が下がってしま
うため, 経済主体は金融市場への貸し付け (=預金) を控え, 借金をする傾向が増進する. その結果金融 需要が増進し, 金利が上昇していくこととなる。方， デフレ期には貨幣の価值が上昇していくため, 各経 済主体はインフレ期とは逆に，借金を控え，金融市 場への貸し付け (=預金)を増加させる傾向が向上 寸る. その結果，金利は低下していくととなる.

言い替えるなら, 金融市場においても, インフレ期 には需要が供給を上回っている一方, デフレ期には 需要が供給を下回るのである.

それ故, 政府が公債発行をする, あるいは, その発 行額を増加させるといら行為が金融市場に及ぼす影 響も, インフレ期とデフレ期で異なったものとなる.

まず, インフレ期においては, 金融の需要が供給を 上回っているため, 公債発行によって金融需要をさら に増加させると, 金融市場の供給不足がさらに進行 し，金利が上昇することとなる.これが，一般的にマク ロ経済学で言われる“クラウディングアウト”といら現象 である4). 11), 16)17)。つまり, 公債発行によって, 金利が 上昇し，民間の経済主体が，資金を調達しずらくなり， 民間の経済活動が抑制されてしまうのである ${ }^{[1]}$.

その一方で, デフレ期においては, 金融需要が供 給を下回っているため, 公債発行を行っても(それが 需要の不足分を超過しない限り) 金融市場において 供給不足が生ずることはなく, 金利が上昇する傾向 は小さい. それよりもむしろ, 金融市場における需給 間のインバランスを低減させ, 預金超過金(金融機関 における貸付額から貸付額を差し引いた金額)を減 少させることを通じて，金融市場でだぶついた資金の 有効利用を促すこととなる ${ }^{[2]}$.

\section{（3）インフレ・デフレ期と税金 /公債発行につ いて}

次に, 以上の議論を踏まえて, 公共事業関係費を 調達するために「税金」を用いる場合と「公債発行」を 行う場合との相違について, 論ずることとしたい. なお ここでは, 税金ではなくて公債発行を重視した財源 調達方法を「公債発行重視」と呼称する. その一方で, 公債発行ではなく税金を重視した財源調達方法を 「税金重視」と呼称することとする ${ }^{[3]}$.

さて, 先の節で述べた議論を踏まえると, 財源調達 の「方法」がマクロ経済に及ぼす影響は，その「水準 
の多寡」が及ぼした影響についての議論と同様に, イ

表 1 インフレ期／デフレ期のそれぞれにおける財源 調達方法の相違の影響

\begin{tabular}{|c|c|c|}
\hline & インフレ期 & デフレ期 \\
\hline $\begin{array}{c}\text { 公債よりも税金 } \\
\text { を重視した調達 } \\
\text { (税金重視) }\end{array}$ & $\begin{array}{c}\text { (適切な税政により) } \\
\text { インフレの抑制 }\end{array}$ & デフレの促進 \\
\hline $\begin{array}{c}\text { 税金よりも公債 } \\
\text { を重視した調達 } \\
\text { (公債発行重 } \\
\text { 視) }\end{array}$ & $\begin{array}{c}\text { 金利の上昇=クラ } \\
\text { ウディングアウトが } \\
\text { 生ずる }\end{array}$ & $\begin{array}{c}\text { 金利上昇=クラウ } \\
\text { ディングアウトが } \\
\text { 生じない }\end{array}$ \\
\hline
\end{tabular}

ンフレ期にあるかデフレ期にあるかで異なるものとな る(表 1 参照).

まず,インフレ期に「税金重視」を採用すれば, 適切 な税制を選択すればそのインフレを抑制することが 可能となると期待できる ${ }^{[4]}$ 一方, 「公債発行重視」を採 用すると, 金利が上昇し, クラウディングアウトを誘発 することを通じて，民間の経済発展を阻害してしまう 可能性がある.

一方, デフレ期に「増税重視」を採用すると, その増 税が消費税等の需要を縮退させる種類の税金につ いてのものである場合, デフレをさらに進行させる危 険性が高い ${ }^{[5]}$. その一方で, デフレ期に「公債発行 重視」を採用しても, インフレ期に見られた金利上昇 に伴うクラウディングアウトは生ずる傾向は低い. むし ろ, 金融市場に於いて借り手が無く“だぶついて”い る預金超過金を活用する方途を提供する傾きが強 い.

以上の議論を踏まえると, インフレ期においては 「税金重視」の調達方法を採用することが得策であり, デフレ期においては「公債発行重視」の調達方法を 採用することが得策である可能性が高いと考えられる こととなる。

\section{3.「公債の償還」について}

以上，「財源調達時点」における，その金額の水準 と調達方法が, マクロ経済の動向に及ぼす影響を論 じた.

ただし，「公債」については, 政府はそれを償還する （すなわち，借金を返済する）義務を負っていることか ら, その点にも配慮することも必要である.

\section{（1）公債の償還を加味した, 公債発行のマクロ 経済効果についての議論}

これまでの公債についてのマクロ経済学的な議論 では, リカードの中立性仮説やフリードマンの「恒常 所得仮説」,さらにはルーカスの「合理的期待形成仮 説」といった諸議論を踏まえて, 公債の償還を視野に 含めると, 公債発行によって得られる短期的な正のマ クロ経済効果は相殺されるであろうという議論がなさ れることがしばしばであった ${ }^{16), 18), 19), 20)}$. 例えば、先 にも紹介した様な「クラウディングアウトが生ずるため 公債発行による公共投資には結局効果は無い」とい う短期的な議論に加えて、長期的な視点からも「公債 発行による現世代の経済成長は, その公債を償還す る将来世代の増税を導きそれを通じた将来世代の経 済の停滞をもたらすので,トータルとしての経済効果 はない「「各世帯が合理的な期待を形成して消費・貯 蓄を調整するので, 公債発行の効果は存在しない」 等と考えられたからである.

しかし，こうした公債やそれに基づく公共投資に関 するこれまでの様々な議論においては, 図 1 に示し た「潜在成長率の維持」や「デフレの抑止」が考慮さ れていないのが一般的である. また, 清水 ${ }^{16)}$ が指摘 しているように, それらの議論では, 非自発的な失業 者が存在するデフレ経済の存在そのものがそもそも 想定されていないのが一般的である. それ故これら の点を踏まえるなら公債発行と償還を巡る議論は上 述のような議論とは異なったものとならざるを得ない.

ついてはここでは,

1)マクロ経済状況には, デフレ期やインフレ期 が存在しているといらこと, ならびに，

2) デフレ期に公共投資を行うことで, 潜在成長 率を維持したり,デフレを抑制したりするよう な「長期的経済効果」が存在していること， の2点を踏まえた上で, 改めて, 公債の「償還」の問 題を考えることとしたい.

\section{（2）公債償還の財源調達方法について}

「公債」は通常, それが発行される際に, その償還 期日が決められている.したがって政府は, その公債 を発行すれば, その公債を購入した経済主体に対し て，その償還期日に債務を返還しなければならない. したがってこの事は, 公債を発行した時点で将来の 
それぞれ時点での(金利の支払いを加味した)「公債 償還の規模」を決定していることを意味している.

そして万一,「公債償還」が不能な年次が発生した 時, 政府は「破綻した」と言われることとなる. それ故, そうした破綻を回避するためには, 政府は公債を発 行する以上は予め決められた期日において公債を 償還するための財源を調達することが必要になる.

したがって「公債償還の問題」を考えるということは すなわち, その年次の「財源調達の問題」を考えると いうこととなる. それ故この問題については, 先の章 で述べた財源調達の議論をそのまま援用できる.

まず, 公債償還時点が「インフレ期」にあるなら, 需 要を抑制してインフレを是正する経済対策を行うこと が必要である. それ故, 公債償還の財源は, 需要の 縮退を導きうる様な「税金」で賄うことが得策となる. そ して, その時点での税収で償還金額を賄うことができ ないのなら, (クラウディングアウトを誘発し, かつ, イ ンフレを助長する公債発行ではなく)「増税」を行うこ とが得策となる ${ }^{[6]}$.

一方, その時点が「デフレ期」であるなら, 増税を行 えばさらにデフレが促進してしまう一方で, 公債を発 行しても民業圧迫＝クラウディングアウトが生ずる危 険が低いため, 公債を発行して財源を調達すること が, 得策となる ${ }^{[7][8]}$.

この様に考えると, デフレ対策として, 公共事業の ために公債を大量に発行し, そしてその後に償還期 日を迎えたとしても, その償還時点でのマクロ経済状 況をよくよく勘案しながら,「増税」か「公債発行」かを 適正に選択しながら財源調達を行えば, インフレ不 況やデフレ不況を深刻化させることは無いのである ${ }^{[9]}$. それよりもむしろ, そうした適正な税政や公債発行は， インフレ不況やデフレ不況の傾向を「抑制」して, 健 全なマクロ経済状況をもたらすことにすら貢献し得る のである.

\section{（3）日本政府が破綻するための条件}

この様に, その時々のマクロ経済状況を勘案しなが ら, 公債償還のための財源調達方法を適切に調整し ていくのなら, 日本政府が債務を期日までに返済で きなくなる, といらいわゆる「破綻」する事態を避けるこ とができる.

しかし,「公債償還」において次のような誤った対応
を採ると, 将来の「政府の破綻」を導くリスクを背負うこ ととなる.

1）インフレ期の大量の公債発行 : インフレ期に おいて, 公債償還の財源調達のために大量の 公債を発行すると, 金利が高騰し, 公債償還 時に財源調達能力を超過する債務を政府が負 うリスクが増進する.

2）デフレ期の大幅増税:デフレ期において, 公債償 還の財源調達のために増税を行うと, 一時的に 政府の財源調達能力を向上させるものの, デフレ をさらに促進することとなる. そしてそれを通じて， 日本経済全体の供給能力 (生産力)の中長期的 な縮退と, 将来の税収の大幅な落ち込みをもたら す. その結果, 政府が返済不能となるリスクが増 進する.

3）外債の大量発行: 外債, 寸なわち, 外国人投 資家に向けて公債を大量に発行すると, 日本 経済の経常収支を悪化させ, 対外純資産を減 らす, あるいは、対外純負債を増やしてしま うこととなる. その結果, 最終的に政府が破 綻するリスクが生ずることとなる.

これらの内，1），2）については既に前節で論じた議 論と同趣旨の内容であるので繰り返さないが，3）に ついて少し補足すると, そもそも, これまで様々な 国々の政府が「破綻」してきたのだが，それらはいず れも,この破綻リスク 3）が原因となっているのであ る. すなわち, 財政破綻をしてきた国々はいずれも, 「外債の発行」が直接的な原因となっていたのである. そして逆に，「内債」を返済できずに破綻した国々は， 今のところどこにも存在していない21). なぜなら内債 は通常, 自国通貨建ての債券であり, その償還時点 において, 最悪の場合でも「通貨発行権」を行使して 通貨を「印刷」した上で償還することが可能だからで ある. しかも, 内債の場合は, その分の負債は日本国 内のいずれかの経済主体の資産となる上に, その利 息分も，償還時点においては日本国内のいずれか の経済主体の収入となる。したがって, 日本経済その ものの経常収支が変化することはない，そのため，イ ンフレ, デフレに関わらず, 公債を発行する際には常 に, 外債の発行を可能な限り押さえ, できるだけ内債 を発行した国内市場から財源を調達する様に務める ことが得策なのである. 
なお, 外債の場合にも, 自国通貨建て(円建て)の 場合と, 外貨建ての場合の二種類があり, 破綻のリス クは,この前者と後者で異なることとなる.

まず, 外貨通貨建ての場合には, 日本国政府は外 貨を発行する権限を持たない為, 償還時点でその外 貨を準備できる保障は必ずしも無い.つまり, 債務不 履行となる直接的リスク, 言い換えるなら破綻する直 接的リスクを抱えることとなる.

一方, 円建ての場合には, 償還時点で日本国政府 が通貨を発行することが可能であるため, それが直 接的原因で破綻するというリスクを背負うことはない. しかし, その場合でも, 日本経済の経常収支を悪化 させることとなる.もちろん, その悪化(あるいは借金) によって日本経済を活性化させることに成功するなら， 経常収支を長期的に悪化させるとは限らないが，そう した“成功”が得られないリスクも存在する ${ }^{[10] . つ ま り ， ~}$ 例え円建ての外債であっても，それを発行しすぎれ ば，日本経済そのものの経常収支を長期的に悪化さ せてしまうリスクが生ずることとなる. そうした状態が継 続し, 日本経済が諸外国経済に対して負債を負って いる状態が慢性化すると, 着実に金利分の日本経済 の富が, 海外に流出することとなる. ましてやデフレ 状況では, 仮に金利が低くても, あるいは, 仮にゼロ であっても, 貨幣価值が償還時点で上昇してしまうの で, 実質的な日本経済の富の流出がより大きなものと なる. その結果, 日本経済が長期的に弱体化し, 円 の暴落, 日本の公債の長期金利の高騰, さらには, 外国通貨建ての外債を発行せざるを得ない状況に 追い込まれるリスクがそれぞれ増進し, 最終的に, 政 府が破綻するリスクが増大寸ることとなる。

\section{（4）デフレ期における公債発行による公共事業 推進の長期的マクロ経済学的意義}

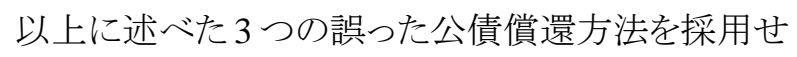
ずに, その時々のインフレ・デフレ状況を踏まえた上 で, 各年時の公債償還のための財源の確保方法を 調整すれば, 財政破綻リスクを回避することができ る.

しかも, 図 1 に示したようにデフレ期に公債を発行し て公共事業を推進することで, デフレを回避し, 潜在 成長率を維持し, かつ, 将来の生産性の向上に寄 与する施設 (インフラ)を整備することができ, 当該の
国のマクロ経済全体の成長を促進することとなる。 そ うなると, 経済は活性化することで税収も増え, かつ, インフレによって貨幣の価值が年々低下していく事を 通じて, 借金の返済がさらに容易なものとなっていく. こうしたことを踏まえると, 公債償還までの期間の全て を考えてもなお, デフレ期において公債発行をして 公共事業を推進することは, それをしない場合よりも， 一国の経済全体を活性化することに寄与しうるもので ある ${ }^{[11]}$.

\section{4.マクロ経済動向への影響を加味した公共事 業関係費の水準と調達方法の調整について}

以上, 本稿では, 既往のマクロ経済に関する議論を 踏まえ，「公共事業関係費の多寡」とその「財源調達 方法」がマクロ経済動向に及ぼす影響を改めて整理 した. そしてそれを踏まえた上で, インフレ状況, デフ レ状況のそれぞれにおいて, 公共事業関係費の財 源調達方法とその水準をどのような考え方に基づい て「調整」していくべきかについての検討を加えた.こ うした議論をまとめると, 以下のようになる.

1) マクロ経済状況がインフレ状況にある時: 基本 的に, インフレ緩和のために緊縮財政を財政の基本 的な考え方に据えることが得策である. そして公共事 業においては, その事業効果を重視する必要は無く, 施設効果の視点から土木計画上必要とされる公共事 業とは何かを考えつつ, 公共事業を推進していくこと が必要である. その際の財源は公債ではなく, 税収 によって財源を調達することが必要である.なお, イ ンフレの程度が強い状況ほど, 公共事業関係費を縮 減し，インフレ抑制を企図した「増税」の可能性も踏ま えながら税収を重視した財源調達方法を採用する方 向へと調整することが必要である.

2) マクロ経済状況がデフレ状況にある時:積極財 政を基本的な考え方に据え, 内需の拡大, 雇用創出 のためにも公共事業関係費をできるだけ多く調達し, 出動していくことで, 様々な事業効果の発現を期し, デフレを緩和していくことが必要である. そのための 財源については, 定常的な税収に加えて公債を, 自 国通貨建ての内債として発行することが得策である. そうすることで, 供給過多の金融市場においてだぶ ついている超過預金を公債の発行によって吸い上げ， 市場に還流していくこを通じて, 雇用創出, 内需拡 
大, デフレ解消を期することが可能となる．ただし， その際の公共事業の内容については, こうした事業 効果に加えて, 土木計画の観点からの施設効果を踏 まえて決定していくこが必要であることは論ずるまで もない(つまり, 財政の考え方で言うなら, “ワイズスペ ンディング”の観点が不可欠である).なお, デフレの 程度が強い状況ほど, より大きな公共事業関係費を 調達し, 出動していくことが必要であり, かつ, その方 法もより公債発行 ${ }^{[12] を}$ 重視したものとしていくことが必 要である.

以上の様に, 市場における「需要」と「供給」の関係, すなわちインフレあるいはデフレがどの程度の水準 にあるのかといらマクロ経済動向を見据えながら,「公 共事業関係費の水準」とその「調達方法」を調整して いくとで, 防災や文化・文明の保全・発展といった 諸目的の達成に加えて, 国民の雇用を確保しつつ 経済成長を促すような政策運営が可能となると期待 される.

\section{注}

[1] ここで, 国際的な金融市場を考えると, 国内の金 融市場の供給不足は, 海外の投資家の投資を呼 び込むこととなる. その結果, インフレ期の公債の 発行は公債における外債 (外国人が購入する公 債)の比率が上昇させ, 内債 (国内の敬愛主体が 購入する公債)の比率を上昇させる傾向を持つ.

[2]一般にこうした状況は「流動性の罠」と呼ばれる. なお,こうした状況であっても, 例えば内乱等の 政情不安などによって公債発行主体の政府に対 する市場における信頼が「極度」に低下している 場合には, 国債需要が必ずしも高まるとは限らな いことも考えられる.

[3] ここでは, 公共事業関係費総額に占める税金に

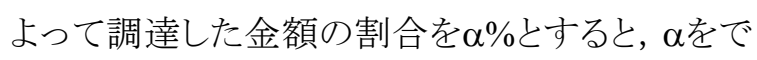
きるだけ大きくしようとする考え方が増税重視， $\alpha$ をできるだけ小さくしようとする考え方が公債発行 重視と定義している.

[4] インフレ期においては消費税等の「需要」を直接 的に抑制する効果を持つ税金を増税することで, インフレを抑制することが可能となる. また, 所得 税・法人税の税率を増加させることでも需要を抑
制することが可能であるが, 得られた税収でもつ て, 内需を拡大寸るような財政出動をしてしまうと, むしろインフレを助長してしまう可能性もある点に 留意が必要である.つまり, 所得税・法人税の場 合には,ただ単にその税率の高低だけで, インフ レやデフレを制御できるとは必ずしも言えない.

[5] ただし, 消費税とは異なり, 所得税・法人税の増 税の影響は, デフレ期とインフレ期でその影響が 異なる. まず, インフレ期においては, 法人も世帯 も貯蓄する傾向が縮退する一方, 借金を優先す る傾向が強くなる. それ故, 消費税や所得税の増 税は, 貯蓄よりもむしろ消費・投資を縮退させる傾 向が強くなる. 一方, デフレ期においては逆に, 法人も世帯も借金する傾向が少ないもの貯蓄を 優先することとなる. その結果, 消費税・所得税増 税は, 消費・投資よりもむしろ, 貯蓄を縮退させる 傾向が強くなる.したがって, デフレ期において は, 消費税・所得税増税は需要を縮退させるとは 限らない一方で, インフレ期においては需要を縮 退させる傾向が強い.

[6] ただし, デフレに突入してしまう程の増税が必要 な場合は, 公債発行と合わせて財源調達をする ことが必要となる。

[7] ただし, 国内の金融市場の需要と供給のギャップ を上回るだけの公債償還額が必要であるなら, そ の全てを公債発行で賄うと, クラウディングアウト が生ずることとなる. それ故, その年次において は, 公債発行に加えて, 増税を行うことが得策と なる.

[8] デフレ期であるなら, 政府が所持している「通貨 発行権」を行使して, 中央銀行の国債の買いオ ペレーション等の金融政策を通して財源を創出 するといら方法を採用することもできる.もちろん， 通貨発行をインフレ期に過剩に行うとマネーサプ ライが過剩となり,さらなるインフレを招く事となる が, デフレ期であるなら通貨を発行してマネーサ プライを拡大することで, デフレが抑制されるとい う効果を期待することもできる.

[9]しばしば, これから高齢化が進み, 金融資産が切 り崩されることが原因で, 将来, 公債償還が困難 となるのではないか, と議論されることがある.し かし, その問題は中央銀行の買いオペレーション 
等の金融政策にて対応する(すなわち, 金融資 産の減少による金利上昇を押さえ込む) という方 法が考えられる.ただしその場合には財市場に おいてインフレ傾向となることが予期される. また， このインフレ傾向は, 高齢化による相対的な需要 の上昇によっても進展する.したがって, そうなれ ば, 本稿で論じている税金重視にて財源調達を 行うことが得策となる.

[10]国内にだぶついた預金超過金が存在しており， 公債を自国経済内で消化可能であるような (2011 年現在の日本のような)状況であるにも拘わらず， わざわざ外債を発行しようとする (=外国人投資 家の日本国債購入を促進しようとする) と，長期的 な経常収支を悪化させるリスクだけを背負うことと なる. したがってそういう状況では, 外債の発行は 可能な限り縮小させ, 内債を発行することが得策 である.

[11]なお,ここで論じたような公共事業ではなく,「将 来世代の政府の税収増進には繋がらない財政 出動のための大量の公債発行」を行うと, 一国の 経済全体に負の影響を与えることもあり得る点に は留意が必要である. 例えば, 平成 22 年度の日 本政府の「子ども手当」のための社会保障関係費 や, 平成 22 年に破綻したギリシャ政府が行った 公務員へのいわゆる「ばらまき」, ならびに, 海外 への投資や輸入などのための公債発行がこれに あたる。 そういら公債発行は, 経済力を増進させ ないままに, 借金だけを膨らませるといら事態を招 く.そうした事態が長年続くと，インフレ期におい ても公債を発行したり, 国内の金融市場の供給 能力を超える公債を発行したりすることを通じて, 財政破綻リスクが増進してしまう. その一方で, 本 文で記載したように, 経済成長に繋がる公債発行 は, それが経済成長に繋がる限り, 破綻のリスク は最小化される.こうした点を踏まえ, 日本の財 政法では公債発行は基本的に禁止されている一 方で, 建設公債の発行については認められてい るのである.これらから, バブル経済崩壊後の小 㴊政権における大量の建設公債発行は, 財政法 の考え方に即したもので，かつ破綻リスクを抱え たものでは無かったことが分かる. 一方平成 22 年 度の政府予算は社会保障関係費や高校無料化
などの, 必ずしも経済成長にはつながり得ない財 政出動のために大量の公債発行がなされたので あることから, 財政法の基本理念を大きく逸脱し た公債発行であったと考えられる. そうした社会 保障関係費は定常的な支出となるものである以 上, 税金で賄わない限り破綻リスクを増進させて しまうものと考えられる。

[12]本稿では十分論じていないが, 少なくともデフレ 時における「公債発行」と類似した対応として「紙 幣印刷」がある. そもそも通貨も公債も, 政府(通 貨については日本銀行, 公債については財務 省) が発行する手形だからである ${ }^{15)}$. 特に, 通貨 発行権のある日本銀行が公債を買い上げる(す なわち, 国債の買いオペレーションといら金融政 策を行う) と, 両者の差異は本質的に消失するこ ととなる.ただし, 公債発行と紙幣印刷では国民 や民間経済主体の印象・反応が異なる点には留 意する必要がある。

\section{参考文献}

1）藤井聡: 土木計画学〜公共選択の社会科学〜, 学外出版, 2008.

2）森杉壽芳 (編) : 社会資本整備の便益評価: 一 般均衡理論によるアプローチ, 勁草書房, 1997.

3) $\mathrm{J} ・ \mathrm{M} ・$ ケインズ $($ 著), 塩野谷 祐一 (訳):『雇用・ 利子および貨幣の一般理論, 東洋経済新報社;, 1995.

4) 小野善康: 景気と経済対策, 岩波新書, 1998.

5) 井堀利宏: 公共事業の正しい考え方一財政赤 字の病理一, 中公新書, 2001.

6) 吉川洋: マクロ経済学研究, 東京大学出版会、 1984.

7) 中野剛志: 恐慌の黙示録一資本主義は生き残 ることができるのか, 東洋経済新報社, 2009.

8) Minsky, H.P.: Can “It” Happen Again?: Essays on Instability and Finance, New York: M.E.Sharp, 1982.

9) Minsky, Hyman P.: Stabilizing An Unstable Economy, New York: McGraw-Hill, 1986]2008.

10) Pigeoon, Marc-André: “”It” Happened, but Not Again: A Minskian Analysis of Japan's Lost 
Dacade', Working Paper No. 303, The Jerome Levy Economics Institute of Bard College, 2000.

11）岩本康志, 大竹文雄, 斎藤誠, 二神孝一: 経済 政策とマクロ経済学一改革への新しい提言, 日 本経済新聞社, 1999..

12) 吉野 直行 (編集), 中島 隆信 (編集)：公共 投資の経済効果，日本評論社, 1999.

13）中野剛志：公共事業はどのような意味において 無䭾なのか?, 第 41 回土木計画学・研究発表 会, スペシャルセッション「マクロ経済学と土木 計画学の政策的対話」, 発表資料, 2010.

14）中野剛志, 公共事業はどのような意味において 無駄なのか?，土木学会誌，95 (6). 2010 p52-54, 2010.

15）小野善康:「第三の道」への 11 の疑問に応える 〜増税と成長は両立するか〜，中央公論 2010.9, pp. 120-129.

16）清水俊裕：財政赤字の経済分析をめぐって,
(財)三菱経済研究所, 2002.

17) Modigliani,F: Long-Run Implications of Alternative Fiscal Policies and the Burden of the National Debt, Economic Journal, 71, pp. 730-755, 1961.

18）本間正明・武藤恭彦・井堀利宏・阿部暢夫・神 取道宏・跡田直澄:「公債の中立命題: 理論と その実証分析一財源調達方式と家計の反応 一」,経済分析 106, pp. 1-39, 1986.

19）中野英夫：公共投資支出の経済分析，(財)三 菱経済研究所, 1999.

20）貝塚啓明著：財政政策の効果と効率性一サス ティナビリティを求めて, 東洋経済新報社, 2001.

21）鷹宮孝信著・三橋貴明監修：さらば、デフレ不 況, 彩図社, 2010.

(XXX.X.X受付)

\section{A BASIC THOUGHT ON THE APPROPRIATE LEVEL AND THE APPROPRIATE WAY OF DISCRETIONAL RAISING FUND FOR PUBLIC WORKS THAT ACCOUNTS FOR MACRO ECONOMIC INFLUENCES}

\section{Satoshi FUJII \& Tsuyoshi NAKANO}

In this paper, we tried to discuss about the appropriate level of national fund for public works and the appropriate way of raising fund for them that accounts for their macro economic influences. It was then discussed that we have to adopt "austere fiscal policy" during inflation period in order to mitigate the inflation and have to raise fund through tax rather than public bond, and we have to adopt "positive fiscal policy" during deflation period in order to mitigate deflation, and have to raise fund through inland public bond rather than tax increase.

1工学研究科都市社会工学専攻 075-383-3238, fujii@trans.kuciv.kyoto-u.ac.jp 2 工学研究科都市社会工学専攻 075-383-3238, nakano@trans.kuciv.kyoto-u.ac.jp 